\title{
In vitro assessment of ruminal fermentation, digestibility and methane production of three species of Desmanthus for application in northern Australian grazing systems
}

\author{
Sophie Vandermeulen ${ }^{\mathrm{A}, \mathrm{B}, \mathrm{C},{ }^{*},}$, Sultan Singh ${ }^{\mathrm{A}, \mathrm{D},{ }^{*}}$, Carlos Alberto Ramírez-Restrepo $^{\mathrm{A}, \mathrm{H}}$, \\ Robert D. Kinley ${ }^{\mathrm{A}}$, Christopher P. Gardiner ${ }^{\mathrm{E}}$, Joseph A. M. Holtum ${ }^{\mathrm{F}}$, Iain Hannah ${ }^{\mathrm{G}}$, \\ and Jérôme Bindelle ${ }^{\mathrm{B}}$ \\ ${ }^{A}$ CSIRO Agriculture, Australian Tropical Sciences and Innovation Precinct, Building 145, James Cook Drive, \\ James Cook University, Townsville, Qld 4811, Australia. \\ ${ }^{B}$ University of Liège, Gembloux Agro-Bio Tech, Precision Livestock and Nutrition Unit, 2 Passage des Déportés, \\ 5030 Gembloux, Belgium. \\ ${ }^{\mathrm{C}}$ Research Foundation for Industry and Agriculture - National Scientific Research Foundation (FRIA-FNRS), \\ 5 Rue d'Egmont, 1000 Bruxelles, Belgium. \\ DIndian Grassland and Fodder Research Institute, Plant Animal Relationship Division, Jhansi 284003, UP, India. \\ EJames Cook University, School of Veterinary and Biomedical Sciences, Building 87, James Cook Drive, \\ Townsville, Qld 4811, Australia. \\ FJames Cook University, Terrestrial Ecosystems and Climate Change, College of Marine and Environmental \\ Sciences, Building 28, James Cook Drive, Townsville, Qld 4811, Australia. \\ ${ }^{\mathrm{G}}$ Agrimix Pty Ltd, Eagle Farm, 19 Chapman Place PO Box 1045, Qld 4009, Australia. \\ ${ }^{\mathrm{H} C}$ Corresponding author. Email: carlosramirez720@yahoo.com \\ *oint first authors.
}

\begin{abstract}
Three species of Desmanthus adapted to the heavy clay soils of northern Australia were studied to determine their nutritive value and effects on in vitro fermentation with rumen fluid, compared with Rhodes grass (Chloris gayana) hay. Leaves and stems of D. leptophyllus cv. JCU 1, D. virgatus cv. JCU 2 and D. bicornutus cv. JCU 4 were collected in summer, winter and spring of 2014 and analysed for chemical composition. Apparent digestibility as in vitro organic matter digestibility (IVD-OM) and fermentation parameters including methane $\left(\mathrm{CH}_{4}\right)$ production were measured during 72-h fermentations using rumen fluid from steer donors grazing tropical grasses and legumes. Desmanthus bicornutus was on average more digestible than both D. leptophyllus and D. virgatus at 24, 48 and $72 \mathrm{~h}$ of incubation. This species also demonstrated an anti-methanogenic potential, in particular when harvested in summer with a reduction in $\mathrm{CH}_{4}$ production of $26 \%$ compared with Rhodes grass hay after $72 \mathrm{~h}$ of incubation. At this time point, D. leptophyllus produced higher volatile fatty acids (VFA per g of organic matter fermented) compared with the other forages. This legume also reduced the $\mathrm{CH}_{4}$ production up to $36 \%$ compared with the Rhodes grass hay reference. However, D. leptophyllus showed lower IVD-OM. Overall, Desmanthus species produced lower in vitro $\mathrm{CH}_{4}$ and lower volatile fatty acids concentration compared with the reference grass hay. These effects may be due to presence of secondary compounds such as hydrolysable tannins, condensed tannins and/or their combination in Desmanthus species. The IVD-OM was influenced by the season after $72 \mathrm{~h}$ of incubation; the digestibility was higher in plants collected in spring. This study suggests that contrasting fermentative profiles in Desmanthus cultivars may offer the opportunity to reduce the greenhouse gas contribution of the beef industry. The next step in demonstration of these promising in vitro results is demonstration of Desmanthus in vivo as proof of concept confirming the productivity and $\mathrm{CH}_{4}$ reduction ability of these legumes in the pastoral systems of northern Australia.
\end{abstract}

Additional keywords: digestion, greenhouse gas, legume, ruminant, tannins.

Received 21 September 2016, accepted 15 June 2018, published online 14 July 2018

\section{Introduction}

Grazing beef production systems in northern Australia are affected by annual dry periods extending usually from April to October. In this scenario, forage availability and its quality are limiting factors that reduce animal productivity and farm profitability (Cox and Gardiner 2013). To mitigate the effect 
of low availability and low quality, the use of improved grass, shrub and legume species to increase nutritive quality of native pasture and beef productivity has been a common, but costly practice (Shelton et al. 1991; Dalzell et al. 2006; Hill et al. 2009). However, not all species adapt equally to variable soil and climatic conditions that prevail on rangelands (Vera and Seré 1985; Durmic et al. 2017; Vandermeulen et al. 2018). Therefore, finding adapted herbaceous and shrub legumes that thrive on the heavy clay soils (i.e. vertosols soils; grey, brown and or black cracking soils with a clay field texture in semiarid environments) is challenging (Isbell and NCST 2016; Vandermeulen 2016), but species from the genus Desmanthus are among the few to be successfully adapted to those conditions in northern Australia (Pengelly and Conway 2000; Gardiner and Swan 2008; Gardiner et al. 2013).

Recently, new Desmanthus cultivars (cv. JCU 1 to 5) described by Loch (2015) and Gardiner (2016), have become available. Among them, D. leptophyllus cv. JCU 1, D. virgatus cv. JCU 2 and $D$. bicornutus cv. JCU 4 have been marketed and established as a blend of the three species (Gardiner et al. 2013). These Desmanthus cultivars comprise a wide range of early to late maturity types, herbaceous to suffruticose plant habits, and edaphic and climatic tolerances. These legumes have also been associated with improved animal production. In Queensland, according to Gardiner and Parker (2012) steers grazing a Desmanthus-buffel grass (Cenchrus ciliaris) paddock during 90 days (i.e. winter) achieved $40 \mathrm{~kg}$ more weight gain than steers only grazing buffel grass. Furthermore, a mixture of Desmanthus with Mitchell grass (Astrebla spp.) increased wool production by up to $34 \%$ in grazing sheep (Rangel and Gardiner 2009).

In contrast, detrimental effects have been demonstrated in growing goats. Compared with Leucaena leucocephala, Kanani et al. (2006) showed reduced animal preference of $D$. bicornutus resulting in low liveweight gain. Although both species contain common secondary metabolites such as condensed tannins (CT; Gonzalez-V. et al. 2005; Tan et al. 2011) that mitigate pastoral $\mathrm{CH}_{4}$ emissions in large (Grainger et al. 2009) and small ruminant systems (Ramírez-Restrepo et al. 2010), the toxic alkaloid mimosine is not present in Desmanthus spp. (Cook et al. 2005).

Therefore, it is obvious that improvements in productivity of low input beef pastoral systems require at least the association of palatable and productive grasslands to complement native forage communities (Department of Primary Industries Queensland 1988, 1999; Vera and Ramírez-Restrepo 2017; RamírezRestrepo and Vera 2018). However, any attempt to achieve sustainable tropical pastoral production requires an integrated mitigation framework that considers profiles of plant-rumen fermentation characteristics as one of the key elements (Ramírez-Restrepo and Charmley 2015). This approach will help improve nutrition balance, body growth, reproduction and cattle welfare (Provenza et al. 2007; Manteca et al. 2008; Provenza and Villalba 2010; Vera and Ramírez-Restrepo 2017). In this respect, Desmanthus cultivars may contribute to improve nutrition for pastures and as an additional effect may mitigate $\mathrm{CH}_{4}$ emission from grazing cattle.

Agronomic attributes of members of the Desmanthus genus have been previously demonstrated (Jones and Brandon 1998; Pengelly and Conway 2000; Cook et al. 2005). However, given that forage quality varies markedly with seasons, there are no data that consider the effects of Desmanthus spp. on nutritive values and the fermentability. This includes concentration of tannins and the anti-methanogenic characteristics using grazing animals as donors of rumen content for in vitro incubations, an important omission. The objectives of the present study were to assess nutritive value of three Desmanthus species using herbage collected during three separate seasons and determine their effects on in vitro fermentation. The primary variables of interest were the potential to reduce in vitro $\mathrm{CH}_{4}$ production in fermentations inoculated with rumen fluid from Bos indicus Brahman grazing steers.

\section{Materials and methods}

Study site

The in vitro experimentation constantly used the same Bos indicus Brahman breed rumen-cannulated steers $(n=4,407 \pm$ $9.45 \mathrm{~kg}$ liveweight) as ruminal fluid donors. The experiment was conducted at CSIRO Agriculture at the Australian Tropical Sciences and Innovation Precinct (ATSIP) in Townsville and at the Lansdown Research Station $\left(19^{\circ} 39^{\prime} \mathrm{S}, 146^{\circ} 50^{\prime} \mathrm{E}\right)$. The study followed CSIRO Animal Ethics Committee approved guidelines (A12/2014) and the Australian code of practice for the care and use of animals for scientific purposes (NHMRC 2013).

\section{Plant material harvesting and preparation}

Desmanthus leptophyllus (cv. JCU 1), D. virgatus (cv. JCU 2) and D. bicornutus (cv. JCU 4) were grown in pots under identical agronomic practices in a semi-enclosed greenhouse at the faculty of Agriculture at the University of Queensland. Each species was composed of four groups of five pots and all plants were cut back to $\sim 10 \mathrm{~cm}$ on the 29 January 2014 (Day 0). In parallel, one sample for each Desmanthus species was harvested by Agrimix Pty Ltd (Eagle Farm, Qld, Australia) from the same number of pots at three different growth stages, in summer (March - Day 51), winter (August - Day 189) and spring (October - Day 273) of 2014. The harvesting approach represented the patterns of seasonal dynamics of forage quality and dry matter (DM) production relative to net forage accumulation (Ramírez-Restrepo et al. 2006a). Thus, the initial day of cut (Day 0) was staggered so further cuts (i.e. Days 51, 189 and 273) provided successive overlapping studied seasons (Ramírez-Restrepo et al. 2006a). After collection, samples were immediately stored at $-20^{\circ} \mathrm{C}$ and freeze-dried. Rhodes grass (Chloris gayana) was representatively sampled from commercial local hay and oven-dried at $55^{\circ} \mathrm{C}$ to be used as the reference. All substrates were ground to pass a $1-\mathrm{mm}$ mesh screen using a Cyclotec 1093 Sample Mill (Foss Tecator, Hillerød, Denmark).

\section{Chemical composition}

\section{Proximate analysis}

Forage analysis was performed following standard methodologies (Association of Official Analytic Chemists, AOAC 1995). Procedures 967.03, 942.05, 984.13 and 930.9 were used for dry matter (DM), ash, nitrogen $(\mathrm{N})$ and ether extract (EE) content, respectively. Neutral detergent fibre 
(NDF) without heat-stable $\alpha$-amylase, acid detergent fibre (ADF), cellulose and acid detergent lignin (ADL (sa)) were determined following the procedures of Van Soest et al. (1991). The NDF and ADF were expressed including residual ash.

\section{Phenols and tannins analyses}

Prior to the phenolic fraction assays, pigments were removed from ground samples using diethyl-ether with acetic acid (99: 1 $\mathrm{v} / \mathrm{v}$ ) according to the modified method of Ammar et al. (2004). Depigmented samples were oven-dried at $40^{\circ} \mathrm{C}$ to avoid deterioration of phenolic compounds. The phenol contents i.e. total phenols (TP), total tannins (TT) and CT were extracted using aqueous acetone (70:30 v/v; Makkar 2003).

The TP and non-tannins phenols (NTP) contents in the plant extract were measured by means of the Folin-Ciocalteu reagent method. The TT fraction was determined by the difference between TP and NTP (Makkar 2003). Total phenols, NTP and TT were expressed as tannic acid equivalent. The total CT fraction was expressed as leucocyanidin equivalent and estimated by the n-butanol-HCl method described by Porter et al. (1985). Hydrolysable tannins (HT) content in plant substrate extract were calculated as the difference between the TT and CT (Singh et al. 2005).

\section{In vitro ruminal fermentation}

\section{Rumen inoculum preparation}

Rumen-cannulated Brahman steers grazed together a mix of native and naturalised pasture characterised by farm management at the beginning of the study following a visual assessment of predominant species on the paddock. In decreasing proportion they were Cenchrus ciliaris, Chloris spp., Macroptilium spp., Panicum spp., Urochloa spp., Stylosanthes spp. The approach ensured the absence of Desmanthus species on the paddock to avoid the impact of any confounding factor on the fermentative studied traits. On collection days ( 6 a.m.), liquid and particulate fractions of the rumen content were manually collected from the four quadrants of the rumen of the steers through fistula and conditioned as described by Ramírez-Restrepo et al. (2014) until further processing.

\section{In vitro rumen inoculation and incubation}

The inoculation and in vitro fermentation were performed following the methods described by Kinley et al. (2016). Briefly, the rumen fluid incubation medium was prepared by combining the strained rumen fluid with the Goering and Van Soest (1970) buffer at a ratio of $1: 4(\mathrm{v} / \mathrm{v})$. Rumen media $(125 \mathrm{~mL})$ was added anaerobically to the $39^{\circ} \mathrm{C}$ incubation bottle containing $1 \mathrm{~g}$ of organic matter $(\mathrm{OM})$ of forage sample. Further the inoculated bottles were purged with $\mathrm{N}_{2}$ and capped gas tight with an Ankom RF1 gas production module (Macedon, NY, USA). Bottles were incubated at $39^{\circ} \mathrm{C}$ in an orbital incubator (Ratek, OM11, Boronia, Vic., Australia) at $85 \mathrm{rpm}$.

The experimental scheme yielded a total of 44 bottles and was replicated over three independent fermentation runs as follows:

[3 Desmanthus cultivars (i.e. species) $\times$ three seasons + one Rhodes grass hay reference and one blank (rumen medium only)] $\times$ four bottles $\times$ three fermentation runs.
During each fermentation run, one bottle for each substrate was stopped after 24 and $48 \mathrm{~h}$ and the remaining two bottles were stopped after $72 \mathrm{~h}$, yielding three replicates for measures taken at 24 and $48 \mathrm{~h}$ and six replicates for measurements done at $72 \mathrm{~h}$, i.e. measurements of total gas, $\mathrm{CH}_{4}$ and volatile fatty acid (VFA) productions and the in vitro apparent digestibility of substrate organic matter (IVD-OM). The run was used as the experimental unit.

\section{Total gas and methane production}

The total gas production (TGP) was measured continuously over $72 \mathrm{~h}$ of incubation according to Kinley et al. (2016), with the cumulative pressure recorded every $20 \mathrm{~min}$. The cumulative TGP was obtained by converting the pressure readings to $\mathrm{mL} / \mathrm{g}$ $\mathrm{OM}$ and $\mathrm{mL} / \mathrm{g}$ OM fermented.

In vitro $\mathrm{CH}_{4}$ concentration was measured in headspace samples collected into pre-vacuumed $10-\mathrm{mL}$ vials at the predetermined time series points of incubation $(24,48$ and $72 \mathrm{~h})$. Gas concentration was determined as described by Kinley et al. (2016) using gas chromatography (GC-2014, Shimadzu Corporation, Kyoto, Japan) equipped with a Restek (Bellefonte, PA, USA) ShinCarbon ST 100/120 micropacked column $(2 \mathrm{~m} \times 1 \mathrm{~mm})$ and both flame ionisation detector and thermal conductivity detector. Methane concentration in headspace was converted to $\mathrm{mL} / \mathrm{g} \mathrm{OM}$ and $\mathrm{mL} / \mathrm{g} \mathrm{OM}$ fermented using the TGP by application of the natural gas law.

\section{In vitro apparent digestibility of substrate organic matter and volatile fatty acids analysis}

The IVD-OM and VFA analysis were performed as described by Kinley et al. (2016). Briefly, after gas sample collection, the in vitro fluid was filtered with a $0.5-\mathrm{cm}$ layer of filtration sand. The solid residues were dried $\left(105^{\circ} \mathrm{C}\right)$ and burned $\left(550^{\circ} \mathrm{C} ; 8 \mathrm{~h}\right)$ to determine the IVD-OM. The concentration in VFA in the in vitro fluid samples was measured using a Shimadzu GC-17A equipped with a flame ionisation detector and a Restek Stabilwax-DA fused silica column $(30 \mathrm{~m} \times 0.25 \mathrm{~mm} \times 0.25 \mu \mathrm{m})$, and with ultra purity $\mathrm{N}$ as the carrier gas. Peak detection and integration of VFA were performed with the Shimadzu GC Solution Software.

\section{Statistical analysis}

All statistical analyses were performed using the Statistical Analysis System version 9.4 (SAS Institute, Cary, NC, USA). The chemical composition (i.e. CP, EE, NDF, ADF, cellulose and ADL), the phenols and tannins constituents (i.e. TP, NTP, TT, CT, HT), the in vitro fermentation parameters (i.e. IVD-OM; TGP and $\mathrm{CH}_{4}(\mathrm{~mL} / \mathrm{g}$ OM fermented and $\mathrm{mL} / \mathrm{g} \mathrm{OM})$ and VFA (mmol/L and $\mathrm{mmol} / \mathrm{g} \mathrm{OM}$ fermented) were assessed using the MIXED procedure in a model that considered the fixed effects of Desmanthus species (i.e. D. leptophyllus cv. JCU 1, D. virgatus cv. JCU 2 and D. bicornutus cv. JCU 4), seasons (i.e. summer, winter and spring) and the resulting interaction between species and seasons. The least-squares means (LSM) have been classified according to this interaction. Rhodes grass was used as a reference and was not included in the statistical analysis (Grosse Brinkhaus et al. 2017). The MEANS procedure was performed to calculate the mean of each parameter of the grass hay reference. Pearson's correlations were used to determine the interaction between $\mathrm{CH}_{4}$ production at different incubation 
time points and the phenolic compounds concentration in forage samples. Least-squares means \pm s.e.m. were considered significantly different at $P<0.05$ and tending to differ when $P \leq 0.10$.

\section{Results}

\section{Chemical composition}

As displayed in Table 1, the chemical composition was different between species and seasons. The CP concentration was higher in D. leptophyllus in winter and in D. bicornutus in spring. Compared with the other legumes, Desmanthus virgatus had a high concentration of fibre. Among the legumes, D. bicornutus in winter contained more CT whereas D. leptophyllus in spring more HT (Table 2). Rhodes grass contained less TP, TT, CT and HT than the legumes, and furthermore CT was not detected in the Rhodes grass.

\section{In vitro fermentation}

The in vitro fermentation parameters of the three Desmanthus species and the Rhodes grass hay reference are presented in Table 3. The IVD-OM was significantly different between the three legume species at 24,48 and $72 \mathrm{~h}(P<0.001$; Table 3$)$. Desmanthus bicornutus had on average higher IVD-OM after 24, 48 and $72 \mathrm{~h}$ of incubation in rumen fluid $(P<0.01)$ than D. virgatus, D. leptophyllus (Table 3 ). The IVD-OM values of this species were in the range of those of the reference at $48 \mathrm{~h}$ and $72 \mathrm{~h}$. After $72 \mathrm{~h}$ of incubation, the IVD-OM was significantly different between season $(P<0.001$; Table 3$)$; the collection of Desmanthus cultivars in spring led to a higher digestibility in vitro.

Total gas produced (TGP, mL/g OM fermented) and $\mathrm{CH}_{4}$ $\left(\mathrm{CH}_{4}, \mathrm{~mL} / \mathrm{g} \mathrm{OM}\right.$ fermented; Table 3$)$ were different between
Desmanthus species and seasons after $72 \mathrm{~h}$ (Table 3 ). The TGP (mL/g OM) by D. leptophyllus was lower than the other forage species after $72 \mathrm{~h}$ of incubation $(P<0.05)$. However, when this parameter was expressed relative to the digestibility $(\mathrm{mL} / \mathrm{g} \mathrm{OM}$ fermented), differences became smaller as, TGP of this legume species was similar to that of $D$. virgatus in summer and spring, and to that of $D$. bicornutus in winter. In terms of $\mathrm{CH}_{4}$ production ( $\mathrm{mL} / \mathrm{g} \mathrm{OM}$; Table 3$)$, irrespective of the season, D. leptophyllus produced less in vitro $\mathrm{CH}_{4}$ compared with the other substrates after $72 \mathrm{~h}$ of incubation $(P<0.001)$. Fermentations including the Desmanthus species emitted less $\mathrm{CH}_{4}$ (mL/g OM incubated) than the reference grass hay at $72 \mathrm{~h}$ of incubation. The higher TGP by Rhodes grass hay was associated to greater $\mathrm{CH}_{4}$ production (Table 3). This was also observed with $D$. virgatus in winter. When expressed to the OM fermented ( $\mathrm{mL} \mathrm{CH}_{4} / \mathrm{g}$ OM fermented), D. leptophyllus in summer and winter and $D$. bicornutus in summer displayed lower $\mathrm{CH}_{4}$ production after $72 \mathrm{~h}(P<0.001$; Table 3$)$. Both species produced less $\mathrm{CH}_{4}$ per $\mathrm{g}$ of $\mathrm{OM}$ fermented than the reference after 48 and $72 \mathrm{~h}$.

Methane production $(\mathrm{mL} / \mathrm{g} \mathrm{OM})$ was negatively correlated with TP, with $r$ values in the range -0.55 to $-0.61(P<0.01)$. This was also observed with TT $(r=-0.58$ to $-0.61 ; P<0.001)$ but not with NTP. Correlation between $\mathrm{CH}_{4}$ production $(\mathrm{mL} / \mathrm{g}$ $\mathrm{OM})$ and HT was higher $(r=-0.71$ at 24 and $48 \mathrm{~h} ; r=-0.64$ at $72 \mathrm{~h} ; P<0.001)$ than with CT $(P>0.05$ at 24 and $48 \mathrm{~h} ; r=-0.33$ and $P<0.05$ at $72 \mathrm{~h}$ ). The same trend was also observed with $\mathrm{CH}_{4}$ per $\mathrm{g}$ of $\mathrm{OM}$ fermented at $24(r=-0.33, P<0.1$ for CT vs $r=-0.60, P<0.001$ for HT) and $48 \mathrm{~h}(r=-0.42, P<0.05$ for CT vs $r=-0.49, P<0.05$ for HT) but with lower $r$-values. However, after $72 \mathrm{~h}$ of incubation the correlation was greater between $\mathrm{CH}_{4}$ production per gram of OM fermented and CT ( $r=-0.62 ; P<0.001$ vs $r=-0.44 ; P<0.01$ for HT).

Table 1. Chemical composition (g/kg DM) of the Desmanthus species and Rhodes grass (Chloris gayana) hay samples processed as technoanalytical triplicates in each season for each forage legume

Least-squares means values among the legumes within the same column followed by the same letters are not significantly different $(P<0.05)$. Comparisons between species, seasons and their interaction in each row for each measurement time are declared at $* P<0.05, * * P<0.01, * * * P<0.001$ and tending to differ when $P \leq 0.10$. ADF, acid detergent fibre; $\mathrm{ADF}$, acid detergent lignin; $\mathrm{CP}$, crude protein $(\mathrm{CP} ; \mathrm{N} \times 6.25)$; DM, dry matter; ether extract (E); NA, not applicable; NDF, neutral detergent fibre; s.e.m., standard error of the mean

\begin{tabular}{|c|c|c|c|c|c|c|c|c|}
\hline Species & Cultivar & Season & $\mathrm{CP}$ & $\mathrm{EE}$ & NDF & $\mathrm{ADF}$ & Cellulose & ADL \\
\hline D. leptophyllus & JCU1 & $\begin{array}{l}\text { Summer } \\
\text { Winter } \\
\text { Spring }\end{array}$ & $\begin{array}{c}170 \mathrm{~b} \\
189 \mathrm{a} \\
135 \mathrm{~cd}\end{array}$ & $\begin{array}{l}49.2 \mathrm{ab} \\
32.4 \mathrm{~d} \\
29.7 \mathrm{~d}\end{array}$ & $\begin{array}{l}470 d \\
495 \mathrm{c} \\
470 \mathrm{~d}\end{array}$ & $\begin{array}{l}271 b \\
240 d \\
238 d\end{array}$ & $\begin{array}{l}212 \mathrm{c} \\
184 \mathrm{e} \\
184 \mathrm{e}\end{array}$ & $\begin{array}{l}59.4 \mathrm{bc} \\
64.9 \mathrm{~b} \\
51.5 \mathrm{de}\end{array}$ \\
\hline D. virgatus & JCU2 & $\begin{array}{l}\text { Summer } \\
\text { Winter } \\
\text { Spring }\end{array}$ & $\begin{array}{l}126 \mathrm{~d} \\
112 \mathrm{e} \\
132 \mathrm{~cd}\end{array}$ & $\begin{array}{l}29.6 \mathrm{~d} \\
18.8 \mathrm{f} \\
25.2 \mathrm{e}\end{array}$ & $\begin{array}{l}525 \mathrm{~b} \\
584 \mathrm{a} \\
458 \mathrm{~d}\end{array}$ & $\begin{array}{l}340 \mathrm{a} \\
340 \mathrm{a} \\
257 \mathrm{c}\end{array}$ & $\begin{array}{l}277 \mathrm{a} \\
271 \mathrm{~b} \\
199 \mathrm{~d}\end{array}$ & $\begin{array}{l}72.7 \mathrm{a} \\
76.1 \mathrm{~b} \\
56.7 \mathrm{~cd}\end{array}$ \\
\hline D. bicornutus & JCU4 & $\begin{array}{l}\text { Summer } \\
\text { Winter } \\
\text { Spring }\end{array}$ & $\begin{array}{r}139 \mathrm{c} \\
174 \mathrm{~b} \\
182 \mathrm{ab}\end{array}$ & $\begin{array}{l}41.7 \mathrm{c} \\
51.0 \mathrm{a} \\
46.6 \mathrm{~b}\end{array}$ & $\begin{array}{l}478 \mathrm{~d} \\
398 \mathrm{e} \\
403 \mathrm{e}\end{array}$ & $\begin{array}{l}273 \mathrm{~b} \\
172 \mathrm{e} \\
171 \mathrm{e}\end{array}$ & $\begin{array}{l}197 \mathrm{~d} \\
130 \mathrm{f} \\
128 \mathrm{f}\end{array}$ & $\begin{array}{l}47.9 \mathrm{ef} \\
41.3 \mathrm{~g} \\
43.7 \mathrm{fg}\end{array}$ \\
\hline C. gayana ${ }^{\mathrm{A}}$ & NA & NA & 135 & 22.4 & 658 & 342 & 297 & 27.6 \\
\hline $\begin{array}{l}\text { Pooled s.e.m. } \\
P\end{array}$ & NA & NA & 4.09 & 1.43 & 6.76 & 4.17 & 1.88 & 1.92 \\
\hline $\begin{array}{l}\text { Species } \\
\text { Season } \\
\text { Species } \times \text { season }\end{array}$ & $\begin{array}{l}- \\
- \\
-\end{array}$ & $\begin{array}{l}- \\
- \\
-\end{array}$ & $\begin{array}{l}* * * \\
* * \\
* * *\end{array}$ & $\begin{array}{l}* * * \\
* * * \\
* * *\end{array}$ & $\begin{array}{l}* * * \\
* * * \\
* * *\end{array}$ & $\begin{array}{l}* * * \\
* * * \\
* * *\end{array}$ & $\begin{array}{l}* * * \\
* * * \\
* * *\end{array}$ & $\begin{array}{l}* * * \\
* * * \\
* * *\end{array}$ \\
\hline
\end{tabular}

\footnotetext{
${ }^{\mathrm{A}}$ Reference (not included in the statistical analysis).
} 
Table 2. Phenols and tannins constituents (g/kg DM) of the leguminous and grass species samples processed as techno-analytical triplicates in each season for each forage legume

Least-squares means values among the legumes within the same column followed by the same letters are not significantly different $(P<0.05)$. Comparisons between species, seasons and their interaction in each row for each measurement time are declared at $* P<0.05, * * P<0.01, * * * P<0.001$ and tending to differ when $P \leq 0.10$. CT, condensed tannins, DM, dry matter; HT, hydrolysable tannins; NA, not applicable; ND, not detected; NS, not significant; NTP, non-tannin phenolics; s.e.m, standard error of the mean; TP, total phenolics; TT, total tannins

\begin{tabular}{|c|c|c|c|c|c|c|c|}
\hline Species & Cultivar & Season & TP & NTP & TT & $\mathrm{CT}$ & HT \\
\hline D. leptophyllus & JCU1 & $\begin{array}{l}\text { Summer } \\
\text { Winter } \\
\text { Spring }\end{array}$ & $\begin{array}{l}79.9 \mathrm{~b} \\
78.2 \mathrm{bc} \\
96.2 \mathrm{a}\end{array}$ & $\begin{array}{l}8.65 \mathrm{ab} \\
7.41 \mathrm{bc} \\
8.64 \mathrm{ab}\end{array}$ & $\begin{array}{l}71.3 \mathrm{~b} \\
70.8 \mathrm{bc} \\
87.6 \mathrm{a}\end{array}$ & $\begin{array}{l}34.1 b \\
36.7 b \\
37.2 b\end{array}$ & $\begin{array}{l}37.1 \mathrm{~b} \\
34.1 \mathrm{~b} \\
50.4 \mathrm{a}\end{array}$ \\
\hline D. virgatus & JCU2 & $\begin{array}{l}\text { Summer } \\
\text { Winter } \\
\text { Spring }\end{array}$ & $\begin{array}{l}36.9 \mathrm{f} \\
40.8 \mathrm{f} \\
49.9 \mathrm{e}\end{array}$ & $\begin{array}{l}6.57 b c \\
4.93 c \\
10.8 a\end{array}$ & $\begin{array}{l}30.3 \mathrm{f} \\
35.9 \mathrm{ef} \\
39.0 \mathrm{e}\end{array}$ & $\begin{array}{l}14.5 \mathrm{~d} \\
23.0 \mathrm{c} \\
25.1 \mathrm{c}\end{array}$ & $\begin{array}{l}15.9 \mathrm{~d} \\
12.9 \mathrm{~d} \\
14.0 \mathrm{~d}\end{array}$ \\
\hline D. bicornutus & JCU4 & $\begin{array}{l}\text { Summer } \\
\text { Winter } \\
\text { Spring }\end{array}$ & $\begin{array}{l}60.7 \mathrm{~d} \\
73.0 \mathrm{c} \\
73.2 \mathrm{c}\end{array}$ & $\begin{array}{l}5.18 \mathrm{c} \\
7.54 \mathrm{bc} \\
9.34 \mathrm{ab}\end{array}$ & $\begin{array}{l}55.5 \mathrm{~d} \\
65.4 \mathrm{bc} \\
63.9 \mathrm{c}\end{array}$ & $\begin{array}{l}34.7 \mathrm{~b} \\
45.3 \mathrm{a} \\
34.2 \mathrm{~b}\end{array}$ & $\begin{array}{l}20.8 \mathrm{~cd} \\
20.1 \mathrm{~cd} \\
29.6 \mathrm{bc}\end{array}$ \\
\hline C. gayana $^{\mathrm{A}}$ & NA & NA & 7.77 & 6.08 & 1.68 & ND & 1.68 \\
\hline $\begin{array}{l}\text { Pooled s.e.m. } \\
P\end{array}$ & NA & NA & 1.96 & 1.09 & 2.43 & 1.92 & 3.43 \\
\hline $\begin{array}{l}\text { Species } \\
\text { Season }\end{array}$ & $\begin{array}{l}- \\
-\end{array}$ & $\begin{array}{l}- \\
-\end{array}$ & $\begin{array}{l}* * * \\
* * *\end{array}$ & $\begin{array}{l}\text { NS } \\
* *\end{array}$ & $\begin{array}{l}* * * \\
* * *\end{array}$ & $\begin{array}{l}* * * \\
* * *\end{array}$ & $\begin{array}{c}* * * \\
*\end{array}$ \\
\hline Species $\times$ season & - & - & $* *$ & $=0.09$ & $*$ & ** & NS \\
\hline
\end{tabular}

${ }^{\mathrm{A}}$ Reference (not included in the statistical analysis).

The total VFA concentration was not different between Desmanthus species in summer, winter and spring seasons (Table 4 for $72 \mathrm{~h}$ of incubation; data not shown for $24 \mathrm{~h}$ and $48 \mathrm{~h}$ ). However, it was on average different between the legume species as $D$. bicornutus and $D$. virgatus produced more VFAs $(\mathrm{mmol} / \mathrm{L})$ than $D$. leptophyllus $(P<0.05)$. The total VFA concentration $(\mathrm{mmol} / \mathrm{L})$ was overall higher for the Rhodes grass hay reference after $72 \mathrm{~h}$ of incubation than the Desmanthus species (Table 4). Similar effect was obtained for acetate and propionate concentrations. However, when total VFA were expressed relative to the digestibility $(\mathrm{mmol} / \mathrm{g} \mathrm{OM}$ fermented; Table 4), the legume cultivars produced similar amounts of VFA compared with Rhodes grass hay; these values were higher for D. leptophyllus.

\section{Discussion}

The objective of the present study was to investigate the effects of the three Desmanthus species collected in three seasons on in vitro fermentation profile including $\mathrm{CH}_{4}$ production using rumen fluid from grazing Brahman steers. The main finding was that, according to the season, D. leptophyllus and/or $D$. bicornutus exhibited the highest anti-methanogenic potential after $72 \mathrm{~h}$ of in vitro rumen fermentation compared with $D$. virgatus. Compared with the Rhodes grass reference, in vitro $\mathrm{CH}_{4}$ production per gram of $\mathrm{OM}$ fermented was reduced by $15-36 \%$ with $D$. leptophyllus (values at $72 \mathrm{~h}$ and $24 \mathrm{~h}$ respectively), and by $10-26 \%$ with $D$. bicornutus (values at $24 \mathrm{~h}$ and $48 \mathrm{~h}$ respectively). This may be due to the presence of secondary compounds such as CT because both species contain the highest concentrations of these molecules. Indeed significant correlations were found between $\mathrm{CT}$ and $\mathrm{CH}_{4}$ production.
Previous studies on sheep and cattle demonstrated the potential of $\mathrm{CT}$ to lower $\mathrm{CH}_{4}$ emissions, either with purified CT extracts (Grainger et al. 2009; Tan et al. 2011) or CTcontaining forages (Tavendale et al. 2005; Hess et al. 2006; Ramírez-Restrepo et al. 2010). However, although the direct effect of HT on the fermentation was not assessed, the antimethanogenic effect of HT or the combination of tannins present in Desmanthus herbage cannot be ruled out because the systemic interrelation among polyphenolic compounds, protein and carbohydrate fractions is complex (Tedeschi et al. 2014; Tedeschi and Fox 2016).

Jayanegara et al. (2015) investigated the impacts of purified $\mathrm{HT}$ and $\mathrm{CT}$ on $\mathrm{CH}_{4}$ emission. They highlighted the anti-methanogenic effect of HT associated to less detrimental impact on digestibility, as CT have been demonstrated to present digestibility issues (Kamalak et al. 2004; Animut et al. 2008). Our study supports the hypothesis that HT could have significant anti-methanogenic properties as we found a significant negative correlation between HT concentration in Desmanthus forages and $\mathrm{CH}_{4}$ emission per g of $\mathrm{OM}$ fermented. Desmanthus leptophyllus and D. bicornutus produced lower $\mathrm{CH}_{4}$ at $72 \mathrm{~h}$ of incubation, and contained higher HT than both D. virgatus and the reference hay (Tables 3 and 2).

However, HT concentration seemed positively related to the lower IVD-OMD observed with D. leptophyllus, which was not the case with CT. Thus, it would seem that the results of our study are not in agreement with other studies (Jayanegara et al. 2015) that have shown that HT had a greater effect in reducing $\mathrm{CH}_{4}$ emission with less adverse effect on digestibility than those of CT. Hydrolysable tannins have been reported to decrease methanogenesis via direct effect as the inhibition of the growth and/or activity of methanogens and/or hydrogenproducing microbes (Bhatta et al. 2009; Jayanegara et al. 


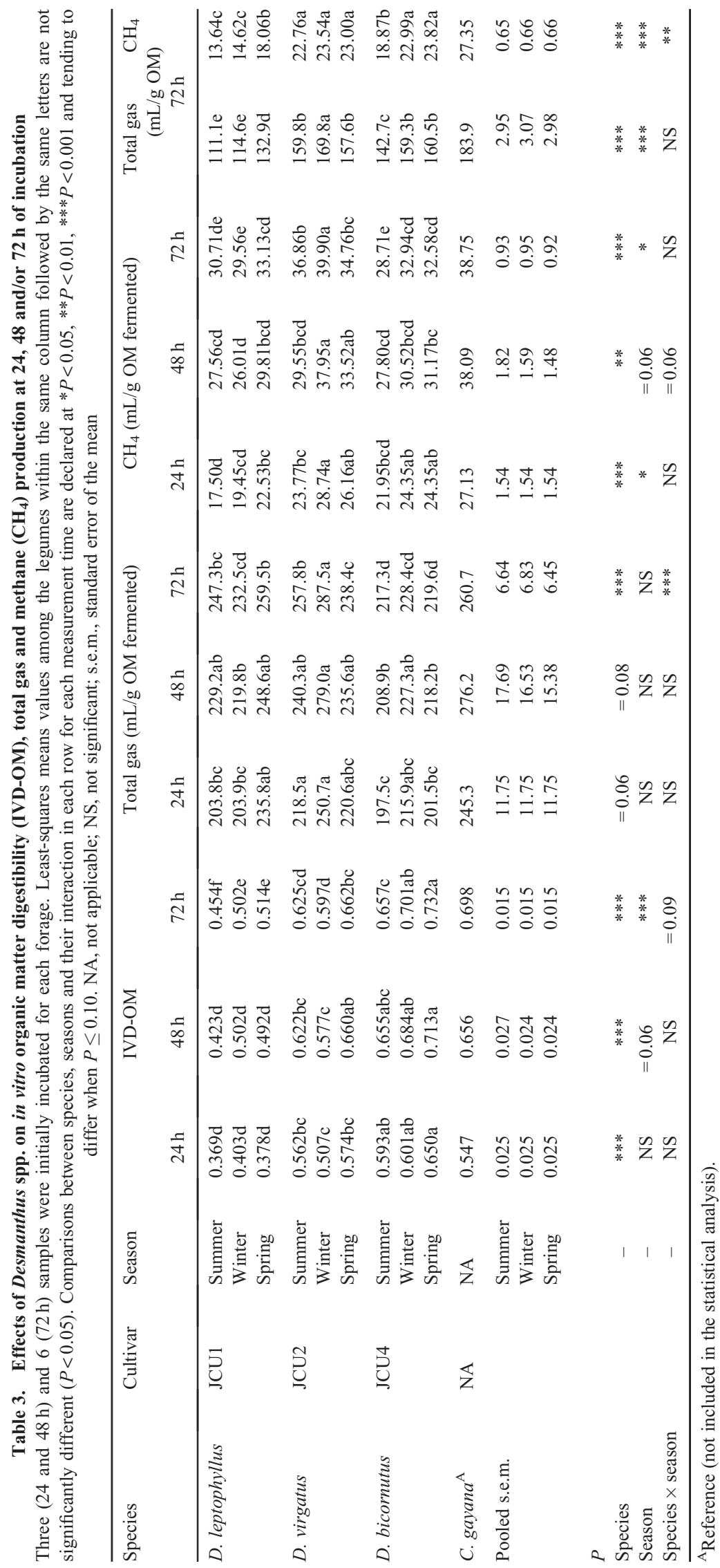


Table 4. Comparative volatile fatty acids concentration ( $\mathrm{mmol} / \mathrm{L})$ between Desmanthus spp. over $72 \mathrm{~h}$ of in vitro incubation with rumen fluid from grazing Brahman steers

Six samples were initially incubated for each forage. VFA, volatile fatty acids. A : P, acetic to propionic acid ratio; A : B, acetic to n-butyric acid ratio. Leastsquares means values among the legumes within the same column followed by the same letters are not significantly different $(P<0.05)$. Differences between species, seasons and their interaction in each row for specific measurement times are declared at $* P<0.05, * * P<0.01, * * * P<0.001$ and tending to differ when $P \leq 0.10$. NA, not applicable; NS, not significant; s.e.m., standard error of the mean

\begin{tabular}{|c|c|c|c|c|c|c|c|c|c|c|c|c|}
\hline \multirow[t]{2}{*}{ Species } & \multirow[t]{2}{*}{ Cultivar } & \multirow[t]{2}{*}{ Season } & \multicolumn{6}{|c|}{ Volatile fatty acids } & \multirow[t]{2}{*}{$A: P$} & \multirow[t]{2}{*}{$A: B$} & \multicolumn{2}{|c|}{ Total VFA } \\
\hline & & & Acetic & Propionic & Iso-butyric & Butyric & Iso-valeric & Valeric & & & $\mathrm{mmol} / \mathrm{L}$ & $\begin{array}{c}\mathrm{mmol} / \mathrm{g} \mathrm{OM} \\
\text { fermented }\end{array}$ \\
\hline \multirow[t]{3}{*}{ D. leptophyllus } & \multirow[t]{3}{*}{ JCU1 } & Summer & 74.6 & $15.4 \mathrm{cde}$ & 1.3 & 10.0 & $2.4 \mathrm{ab}$ & 1.3 & $4.9 \mathrm{ab}$ & $7.6 \mathrm{a}$ & 105.1 & $29.40 \mathrm{a}$ \\
\hline & & Winter & 75.1 & $15.3 \mathrm{de}$ & 1.4 & 10.5 & $2.6 \mathrm{ab}$ & 1.3 & $4.9 \mathrm{ab}$ & 7.4ab & 106.2 & $27.13 \mathrm{ab}$ \\
\hline & & Spring & 75.3 & $14.9 \mathrm{e}$ & 1.2 & 10.8 & $2.2 \mathrm{~b}$ & 1.2 & $5.1 \mathrm{a}$ & 7.2ab & 105.6 & $26.35 b c$ \\
\hline \multirow[t]{3}{*}{ D. virgatus } & \multirow[t]{3}{*}{ JCU2 } & Summer & 81.2 & $17.4 \mathrm{ab}$ & 1.6 & 12.3 & $2.8 \mathrm{ab}$ & 1.5 & $4.7 \mathrm{ab}$ & $6.8 \mathrm{ab}$ & 116.6 & $23.32 d$ \\
\hline & & Winter & 78.5 & $17.7 \mathrm{a}$ & 1.4 & 12.6 & $2.5 \mathrm{ab}$ & 1.3 & $4.4 \mathrm{~b}$ & $6.3 b$ & 114.0 & $23.91 \mathrm{~cd}$ \\
\hline & & Spring & 79.3 & 17.0abcd & 1.5 & 12.4 & $2.8 \mathrm{ab}$ & 1.5 & $4.7 \mathrm{ab}$ & $6.5 \mathrm{ab}$ & 114.4 & $21.61 \mathrm{de}$ \\
\hline \multirow[t]{3}{*}{ D. bicornutus } & \multirow[t]{3}{*}{ JCU4 } & Summer & 75.7 & $15.7 \mathrm{bcde}$ & 1.5 & 11.8 & $2.7 \mathrm{ab}$ & 1.4 & $4.8 \mathrm{ab}$ & $6.5 \mathrm{ab}$ & 108.9 & $20.69 \mathrm{e}$ \\
\hline & & Winter & 81.6 & 17.1abc & 1.5 & 12.2 & $2.8 \mathrm{ab}$ & 1.5 & $4.8 \mathrm{abc}$ & $6.8 \mathrm{ab}$ & 116.7 & $20.79 \mathrm{e}$ \\
\hline & & Spring & 78.8 & 16.5abcde & 1.6 & 12.2 & $3.0 \mathrm{a}$ & 1.6 & $4.8 \mathrm{abc}$ & $6.6 \mathrm{ab}$ & 113.8 & $19.45 \mathrm{e}$ \\
\hline C. gayana $^{\mathrm{A}}$ & NA & NA & 88.5 & 20.1 & 1.7 & 11.0 & 2.9 & 1.7 & 4.4 & 8.3 & 125.9 & 22.53 \\
\hline \multirow[t]{3}{*}{ Pooled s.e.m. } & & Summer & 2.9 & 0.63 & 0.14 & 0.95 & 0.27 & 0.12 & 0.12 & 0.42 & 4.7 & 0.88 \\
\hline & & Winter & 2.9 & 0.63 & 0.14 & 0.95 & 0.27 & 0.12 & 0.12 & 0.42 & 4.7 & 0.88 \\
\hline & & Spring & 2.9 & 0.63 & 0.14 & 0.95 & 0.27 & 0.12 & 0.12 & 0.42 & 4.7 & 0.88 \\
\hline \multicolumn{13}{|l|}{$P$} \\
\hline Species & & - & NS & $* * *$ & NS & $*$ & NS & $=0.07$ & $* *$ & $*$ & * & $* * *$ \\
\hline Season & & - & NS & NS & NS & NS & NS & NS & NS & NS & NS & $*$ \\
\hline Species $\times$ season & & - & NS & NS & NS & NS & NS & NS & NS & NS & NS & NS \\
\hline
\end{tabular}

${ }^{\mathrm{A}}$ Reference (not included in the statistical analysis).

2010). Mechanisms involving HT in Desmanthus plants on methanogenesis need further investigation as this form of tannins is much less documented than CT (Bhatta et al. 2009).

Furthermore, when examining a range of plant secondary compounds for their $\mathrm{CH}_{4}$ reduction attributes, Jayanegara et al . (2015) suggested that measuring the biological activity of metabolites, such as via the assessment of bovine serum albumin protein precipitation capacity (Asquith and Butler 1985), is more accurate than measuring the concentration of compounds in the plant. However, the test of astringency (ability to bind protein) of CT using bovine serum albumin is done in a medium with $\mathrm{pH}$ of 4.9 (McAllister et al. 2005), which is not the $\mathrm{pH}$ found in the rumen. Thus, verification of the biological activity of tannins in Desmanthus species are important using Rubisco as the model protein in a medium with $\mathrm{pH} 7$ comparative to the $\mathrm{pH}$ in the rumen of animals on forage-based diets, and also because this enzyme represents the main protein in fresh fodder (McAllister et al. 2005).

Our results demonstrate that, among the two species presenting an anti-methanogenic potential, Desmanthus bicornutus was more digestible. Desmanthus leptophyllus, which had reduced in vitro gas and $\mathrm{CH}_{4}$ production $(\mathrm{mL} / \mathrm{g}$ $\mathrm{OM}$ ), had lower IVD-OM irrespective of the season compared with the other two Desmanthus forages (Table 3). This observation revealed a contrasting trend when gas and $\mathrm{CH}_{4}$ are expressed per $\mathrm{g}$ of $\mathrm{OM}$ fermented; Desmanthus leptophyllus and D. bicornutus produced then less $\mathrm{CH}_{4}$ at $72 \mathrm{~h}$ of incubation. Although HT appear to decrease $\mathrm{CH}_{4}$ more through a direct effect on reducing methanogenesis, CT would also act indirectly through reducing digestibility of the forage leading to reduced DMI and fibre digestion (Tiemann et al. 2008; Jayanegara et al. 2010). However, in a study designed to separate the effects of CT and fibre on digestibility of tropical legumes containing CT, Tiemann et al. (2008) concluded that low quality and reduced $\mathrm{CH}_{4}$ production of CT-rich legumes are also partly explained by the degradation of fibre in the rumen. Properties of fibre in highly tanniferous plants seem determinant because lignin prevented mainly hemicellulose from degradation through the formation of indigestible complexes, whereas it is suggested that the extent of degradation of hemicellulose have influenced $\mathrm{CH}_{4}$ production.

Moreover, in the Van Soest fibre method, the plant cell has two constituents that are cell wall (hemicellulose, cellulose and lignin) and mostly digestible cell contents (starch and sugars). Then it follows that the difference between plant cell and NDF content represents the cell contents, which is a good estimate of soluble carbohydrates $(\mathrm{CHO})$ content. In our study, these highly fermentable $\mathrm{CHO}$ are higher in D. bicornutus and hence this would induce higher IVD-OM values of this species. This increased fermentability resulted in higher $\mathrm{CH}_{4}$ production, but expressed per $\mathrm{g}$ of fermented $\mathrm{OM}, \mathrm{CH}_{4}$ production in D. bicornutus was on average as low as that of D. leptophyllus, showing the high potential of this species in supplying high value forage with lower methanogenic potential.

Reduced $\mathrm{CH}_{4}$ production accompanied with lower digestibility has been observed in previous research (Animut et al. 2008; Tan et al. 2011). Supplementing goats fed sorghum- 
sudangrass (S. bicolor) with different levels of the CT-containing legume Lespedeza striata (i.e. 1.00, 0.67, 0.33 and 0) reduced $\mathrm{CH}_{4}$ emission, but at relatively low dietary CT levels this was not accompanied by considerable adverse effects on digestion such as total tract $\mathrm{N}$ digestibility (Animut et al. 2008). It is clear that $\mathrm{CT}$ bind protein in the rumen and the $\mathrm{CT}$-protein complex remain stable at pH 5.5-7 (Jones and Mangan 1977), partially resistant to microbial degradation (McLeod 1974; Min et al. 2005). Rumen bypass protein then becomes available for lower digestive tract utilisation (Jones and Mangan 1977), which results in improved feed protein availability to the animal. Therefore, CT-containing Desmanthus spp. may have a beneficial impact on dietary $\mathrm{N}$ efficiency compared with Rhodes grass, but this should be considered within a framework of in vivo studies.

The evolution of plant maturity (Tables 1 and 2) over seasons influenced the rumen fermentation as the IVD-OM and $\mathrm{CH}_{4}$ were different between seasons after $72 \mathrm{~h}$ of incubation (Table 3 ). The lower fibre content in spring (Table 1) might be one reason for the higher plant digestibility during this season. Taking advantage of these differences over grazing season by associating in space and time various plants, including Desmanthus spp., might offer opportunities for ruminants to improve nutrition balance, health and well being (Provenza et al. 2007; Manteca et al. 2008).

Compared with the reference diet, the total VFA, acetate and propionate concentration after $72 \mathrm{~h}$ of incubation (Table 4) were overall reduced for the Desmanthus spp. Volatile fatty acids are the main source of metabolisable energy for ruminants, resulting from the rumen microbial fermentation (Bergman 1990). As a result, a reduction in VFA production is undesired. As VFA result from the fermentation of the diet in the rumen, a lower fermentability may explain lower VFA production, which was observed in this study. However, when VFA production was expressed relative to the IVD-OM, Desmanthus leptophyllus that had the lowest IVD-OM presented the highest VFA production (mmol/g OM fermented; Table 4). It is also known that plant secondary compounds such as tannins may modulate the microbial consortium of the rumen environment including notably modified microbial diversity and activity (McSweeney et al. 2001, 2002), and lead to a reduction in VFA production (Bhatta et al. 2009; Jayanegara et al. 2015). Polyphenolic secondary compounds in the legume species may explain the lower VFA concentration compared with Rhodes grass in which polyphenolics were mostly lower or not detected.

In an in vitro study on tropical legumes with various CT concentration (Barahona et al. 2003), CT-containing Flemingia macrophylla and Desmodium ovalifolium had produced lower total VFA than the non-tanniferous legumes Leucaena macrophyllya as it is observed in our study with Desmanthus forage containing CT compared with the nontanniferous reference grass. However, the relation with $\mathrm{CT}$ in not straightforward as in the study of Barahona et al. (2003) on Calliandra calothyrsus, which had similar or higher CT content produced greater VFA concentration than both F. macrophylla and D. ovalifolium, and Leucaena leucocephala produced higher VFA concentration with CT content in the same range than $D$. ovalifolium.

Although lower VFA production, either due to a low DM digestibility or depressed feed intake, would imply less energy available to the animal; it has been reported that high dietary
CT concentration (i.e. $>50 \mathrm{~g} \mathrm{CT} / \mathrm{kg} \mathrm{DM}$ ) can lead to low feed intake (Barry and Duncan 1984; Waghorn et al. 1994; Bhatta et al. 2002), whereas low amounts in CT-containing legumes (i.e. $<50$ g CT $/ \mathrm{kg} \mathrm{DM}$ ) did not (Wang et al. 1996; Carulla et al. 2005) even as the plant matured (Ramírez-Restrepo et al. 2006b). Other studies, however, have demonstrated that supplementation of Desmanthus spp. to steers fed buffel grass increased weight gain (Gardiner and Parker 2012) or sheep fed Mitchell grass boosted wool production (Rangel and Gardiner 2009).

Other factors than the depression of intake or VFA production might also play a role in animal performance. Because in our study Desmanthus cultivars contained less than $50 \mathrm{~g} \mathrm{CT} / \mathrm{kg}$ $\mathrm{DM}$, it is reasonable to assume that the CT concentration in Desmanthus spp. could enhance rumen metabolism and systemic dynamic physiology (Tedeschi et al. 2014; Tedeschi and Fox 2016) in different ways. Certain CT chemistry (i.e. molecular size and monomer composition) is likely to influence the strength of interaction of tannins with dietary proteins and fibre, and thus forage quality (Barahona et al. 2003). For example, the astringency of $C$. calothyrsus seemed to be related to the tannin structure (Stewart et al. 2000; Lascano et al. 2003). However, it remains important to elucidate the magnitude of significant molecular interactions and the systemic exposure to analogous physiologic mechanisms.

Differences in fermentative traits between the Desmanthus cultivars along the seasons may provide opportunities to minimise the environmental footprint of pastoral systems in northern Australia. However, the degree of further collaboration between the academia, primary producers and agricultural industries will make a major difference to confront the challenges imposed by mitigation imperatives of climate change and the need to cope with a growing food security vulnerability.

\section{Conclusion}

In conclusion, Desmanthus leptophyllus and D. bicornutus demonstrated a greater potential to reduce enteric $\mathrm{CH}_{4}$ after $72 \mathrm{~h}$ of in vitro fermentation compared with the third Desmanthus species. Among these legumes, D. bicornutus was on average more digestible. Collecting plants in different seasons influenced the fermentation as the IVD-OM was overall higher for spring plants after $72 \mathrm{~h}$ of incubation. Furthermore, Desmanthus spp. reduced in vitro $\mathrm{CH}_{4}$ production and VFA concentrations compared with the Rhodes grass reference. The potential impact of Desmanthus spp. on the sustainability of tropical pastoral systems is important, requires in-depth characterisation, and seasonal pastoral experimentation with specific intended outcomes will be of great benefit to the Northern beef industry.

\section{Conflicts of interest}

The authors declare no conflicts of interest.

\section{Acknowledgements}

The present manuscript has been developed based on data presented in the $\mathrm{PhD}$ Thesis of Dr Sophie Vandermeulen in 2016. The authors acknowledge the FRIA-FNRS, CURAGx for provision of Scholarship and travel grants to 
Sophie Vandermeulen. Special thanks are extended to The Commonwealth Scientific and Industrial Research Organisation (CSIRO) for making the internship experience possible for Ms Vandermeulen. We are also grateful to The Australian Endeavour Fellowship program for the financial support provided to Dr Sultan Singh, while in Australia. Appreciation is expressed to the Indian Grassland and Fodder Research Institute (IGFRI) for plant quality laboratory screening. Drs Shane Askew and Matt Vucko are also thanked for their guidance on analytical procedures and data analysis. We are grateful to Nick Kempe, Agrimix Pty Ltd and James Cook University (JCU). Finally, technical support provided by Wayne Flintham and Steve Austin at Lansdown Research Station cannot be forgotten.

\section{References}

Ammar H, López S, González JS, Ranilla MJ (2004) Tannin levels in the foliage of some Spanish shrub species at different stages of development. In 'Options Méditerranéennes: Série A. Séminaires Méditerranéens No. 59. Nutrition and feeding strategies of sheep and goats under harsh climates'. (Eds H Ben Salem, A Nefzaoui, P Morand-Fehr) pp. 159-163. (CIHEAM: Zaragoza)

Animut G, Puchala R, Goetsch AL, Patra AK, Sahlu T, Varel VH, Wells J (2008) Methane emission by goats consuming diets with different levels of condensed tannins from lespedeza. Animal Feed Science and Technology 144, 212-227. doi:10.1016/j.anifeedsci.2007.10.014

AOAC (1995) 'Official methods of analysis of AOAC INTERNATIONAL.' 16th edn. (Association of Official Analytical Chemists: Arlington, VA)

Asquith TN, Butler LG (1985) Use of dye-labeled protein as spectrophotometric assay for protein precipitants such as tannin. Journal of Chemical Ecology 11, 1535-1544. doi:10.1007/BF01012199

Barahona R, Lascano CE, Narvaez N, Owen E, Morris P, Theodorou MK (2003) In vitro degradability of mature and immature leaves of tropical forage legumes differing in condensed tannin and non-starch polysaccharide content and composition. Journal of the Science of Food and Agriculture 83, 1256-1266. doi:10.1002/jsfa.1534

Barry TN, Duncan SJ (1984) The role of condensed tannins in the nutritional value of Lotus pedunculatus for sheep. British Journal of Nutrition 51, 485-491. doi:10.1079/BJN19840054

Bergman EN (1990) Energy contributions of volatile fatty acids from the gastrointestinal tract in various species. Physiological Reviews 70, 567-590. doi:10.1152/physrev.1990.70.2.567

Bhatta R, Shinde AK, Vaithiyanathan S, Sankhyan SK, Verma D (2002) Effect of polyethylene glycol-6000 on nutrient intake, digestion and growth of kids browsing Prosopis cineraria. Animal Feed Science and Technology 101, 45-54. doi:10.1016/S0377-8401(02)00180-3

Bhatta R, Uyeno Y, Tajima K, Takenaka A, Yabumoto Y, Nonaka I, Enishi O, Kurihara M (2009) Difference in the nature of tannins on in vitro ruminal methane and volatile fatty acid production and on methanogenic archaea and protozoal populations. Journal of Dairy Science 92, 5512-5522. doi:10.3168/jds.2008-1441

Carulla J, Kreuzer M, Machmüller A, Hess H (2005) Supplementation of Acacia mearnsii tannins decreases methanogenesis and urinary nitrogen in forage-fed sheep. Crop \& Pasture Science 56, 961-970. doi:10.1071/AR05022

Cook B, Pengelly BC, Brown S, Donnelly JB, Eagles D, Franco A, Hanson J, Mullen BF, Partridge I, Peters M, Schultze-Kraft R (2005) Tropical Forages: an interactive selection tool. CSIRO, DPI\&F (Qld), CIAT and ILRI, Brisbane, Australia. [CD-ROM]. Available at: http://www. tropicalforages.info/ (accessed 22 March 2016)

Cox K, Gardiner C (2013) Pasture legumes in Queensland - a new wave? In 'Proceedings of the Northern Beef Research Update Conference'. Cairns, Qld, Australia, 12-15 August 2013. pp. 15-20. (Queensland North Australia Beef Research Council: Gympie, Qld)

Dalzell SA, Shelton HM, Mullen BF, Larsen PH, McLaughlin KG (2006) 'Leucaena: a guide to establishment and management.' (Meat \& Livestock Australia Ltd.: Sydney, NSW)
Department of Primary Industries Queensland (1988) 'Native pastures in Queensland. The resources and their management.' (Department of Primary Industries, Queensland Government: Brisbane)

Department of Primary Industries Queensland (1999) 'Managing grazing in northern Australia.' (Department of Primary Industries, Queensland Government: Brisbane)

Durmic Z, Ramírez-Restrepo CA, Gardiner C, O’Neill CJ, Hussein E, Vercoe PE (2017) Differences in the nutrient concentrations, in vitro methanogenic potential and other fermentative traits of tropical grasses and legumes for beef production systems in northern Australia. Journal of the Science of Food and Agriculture 97, 4075-4086. doi: $10.1002 /$ jsfa. 8274

Gardiner CP (2016) Developing and commercializing new pasture legumes for clay soils in the semi-arid rangelands of northern Australia: The new Desmanthus cultivars JCU 1-5 and the Progardes story. In 'Tropical forage legumes. Harnessing the potential of Desmanthus and other genera for heavy clay soils'. (Eds JR Lazier, N Ahmad) pp. 283-304. (CABI: Boston, MA, USA)

Gardiner C, Parker AJ (2012) Steer liveweight gains on Progardes ${ }^{\mathrm{TM}}$ Desmanthus/buffel pastures in Queensland. In 'Proceedings of Second Joint Conference of the New Zealand Society of Animal Production and the Australian Society of Animal Production'. Lincoln University, Christchurch, New Zealand, 2-5 July 2012. (Eds MA Friend, GL Krebs) pp. 1. (Lincoln University: Christchurch, New Zealand)

Gardiner CP, Swan SJ (2008) Abandoned pasture legumes offer potential economic and environmental benefits in semiarid clay soil rangelands. In 'A climate of change in the rangelands. Australian Rangeland Society, 15th Biennial Conference Proceedings'. 28 September-2 October 2008, Charters Towers, Qld. (CD-ROM) (Australian Rangeland Society: Mount Lawley, WA)

Gardiner C, Kempe N, Hannah I, McDonald J (2013) PROGARDES ${ }^{\mathrm{TM}}$ : a legume for tropical/subtropical semi-arid clay soils. Tropical Grasslands-Forrajes Tropicales 1, 78-80. doi:10.17138/TGFT(1)78-80

Goering HK, Van Soest PJ (1970) 'Forage fiber analyses (apparatus, reagents, procedures, and some applications).' Agriculture Handbook No. 379. (ARS-USDA: Washington, DC)

Gonzalez-V EA, Hussey MA, Ortega-S JA (2005) Nutritive value of Desmanthus associated with Kleingrass during the establishment year. Rangeland Ecology and Management 58, 308-314. doi:10.2111/ 1551-5028(2005)58[308:NVODAW]2.0.CO;2

Grainger C, Clarke T, Auldist MJ, Beauchemin KA, McGinn SM, Waghorn GC, Eckard RJ (2009) Potential use of Acacia mearnsii condensed tannins to reduce methane emissions and nitrogen excretion from grazing dairy cows. Canadian Journal of Animal Science 89, 241-251. doi:10.4141/CJAS08110

Grosse Brinkhaus A, Wyss U, Arrigo Y, Girard M, Bee G, Zeitz JO, Kreuzer M, Dohme-Meier F (2017) In vitro ruminal fermentation characteristics and utilisable $\mathrm{CP}$ supply of sainfoin and birdsfoot trefoil silages and their mixtures with other legumes. Animal 11, 580-590. doi:10.1017/S1751731116001816

Hess HD, Tiemann TT, Noto F, Carulla JE, Kreuzer M (2006) Strategic use of tannins as means to limit methane emission from ruminant livestock. International Congress Series 1293, 164-167. doi:10.1016/j.ics.2006. 01.010

Hill JO, Coates DB, Whitbread AM, Clem RL, Robertson MJ, Pengelly BC (2009) Seasonal changes in pasture quality and diet selection and their relationship with liveweight gain of steers grazing tropical grass and grass-legume pastures in northern Australia. Animal Production Science 49, 983-993. doi:10.1071/EA06331

Isbell R, National Committee on Soil and Terrain (2016) 'The Australian Soil Classification.' 2nd edn. (CSIRO Publishing: Melbourne) Available at: http://www.clw.csiro.au/aclep/asc_re_on_line_V2/ve/vertsols.htm

Jayanegara A, Goel G, Makkar HPS, Becker K (2010) Reduction in methane emissions from ruminants by plant secondary metabolites: 
Effects of polyphenols and saponins. In 'Sustainable improvement of animal production and health'. (Eds NE Odongo, M Garcia, GJ Viljoen) pp. 151-157. (FAO: Rome)

Jayanegara A, Goel G, Makkar HPS, Becker K (2015) Divergence between purified hydrolysable and condensed tannin effects on methane emission, rumen fermentation and microbial population in vitro. Animal Feed Science and Technology 209, 60-68. doi:10.1016/ j.anifeedsci.2015.08.002

Jones RM, Brandon NJ (1998) Persistence and productivity of eight accessions of Desmanthus virgatus under a range of grazing pressures in subtropical Queensland. Tropical Grasslands 32, 145-152.

Jones WT, Mangan JL (1977) Complexes of the condensed tannins of sainfoin (Onobrychis viciifolia Scop.) with fraction 1 leaf protein and with submaxillary mucoprotein, and their reversal by polyethylene glycol and pH. Journal of the Science of Food and Agriculture 28, 126-136. doi:10.1002/jsfa.2740280204

Kamalak A, Filho JMP, Canbolat O, Gurbuz Y, Ozay O, Ozkan CO (2004) Chemical composition and its relationship to in vitro dry matter digestibility of several tannin-containing trees and shrub leaves. Livestock Research for Rural Development 16, 1-5.

Kanani J, Lukefahr SD, Stanko RL (2006) Evaluation of tropical forage legumes (Medicago sativa, Dolichos lablab, Leucaena leucocephala and Desmanthus bicornutus) for growing goats. Small Ruminant Research 65, 1-7. doi:10.1016/j.smallrumres.2005.04.028

Kinley RD, de Nys R, Vucko MJ, Machado L, Tomkins NW (2016) The red macroalgae Asparagopsis taxiformis is a potent natural antimethanogenic that reduces methane production during in vitro fermentation with rumen fluid. Animal Production Science 56, 282-289. doi:10.1071/AN15576

Lascano C, Avila P, Stewart J (2003) Intake, digestibility and nitrogen utilization by sheep fed with provenances of Calliandra calothyrsus Meissner with different tannin structure. Archivos Latinoamericanos de Producción Animal 11, 21-28.

Loch DS (2015) Desmanthus varieties JCU1-5 descriptors. Plant Varieties Journal 28, 59-192.

Makkar HP (2003) 'Quantification of tannins in tree and shrub foliage: a laboratory manual.' (Kluwer Academic Publishers: Dordrecht, The Netherlands)

Manteca X, Villalba JJ, Atwood SB, Dziba L, Provenza FD (2008) Is dietary choice important to animal welfare? Journal of Veterinary Behavior: Clinical Applications and Research 3, 229-239. doi:10.1016/ j.jveb.2008.05.005

McAllister TA, Martinez T, Bae HD, Muir AD, Yanke LJ, Jones GA (2005) Characterization of condensed tannins purified from legume forages: chromophore production, protein precipitation, and inhibitory effects on cellulose digestion. Journal of Chemical Ecology 31, 2049-2068. doi:10.1007/s10886-005-6077-4

McLeod MN (1974) Plant tannins - their role in forage quality. Nutrition Abstracts and Reviews 44, 803-815.

McSweeney CS, Palmer B, McNeill DM, Krause DO (2001) Microbial interactions with tannins: nutritional consequences for ruminants. Animal Feed Science and Technology 91, 83-93. doi:10.1016/S03778401(01)00232-2

McSweeney CS, Odenyo A, Krause DO (2002) Rumen microbial responses to antinutritive factors in fodder trees and shrub legumes. Journal of Applied Animal Research 21, 181-205. doi:10.1080/09712 119.2002.9706369

Min BR, Attwood GT, McNabb WC, Molan AL, Barry TN (2005) The effect of condensed tannins from Lotus corniculatus on the proteolytic activities and growth of rumen bacteria. Animal Feed Science and Technology 121, 45-58. doi:10.1016/j.anifeedsci.2005.02.007

NHMRC (2013) 'Australian code for the care and use of animals for scientific purposes.' 8th edn. (National Health and Medical Research Council: Canberra)
Pengelly BC, Conway MJ (2000) Pastures on cropping soils: which tropical pasture legume to use? Tropical Grasslands 34, 162-168.

Porter LJ, Hrstich LN, Chan BG (1985) The conversion of procyanidins and prodelphinidins to cyanidin and delphinidin. Phytochemistry 25, 223-230. doi:10.1016/S0031-9422(00)94533-3

Provenza FD, Villalba JJ (2010) The role of natural plant products in modulating the immune system: An adaptable approach for combating disease in grazing animals. Small Ruminant Research 89, 131-139. doi:10.1016/j.smallrumres.2009.12.035

Provenza FD, Villalba JJ, Haskell J, MacAdam JW, Griggs TC, Wiedmeier RD (2007) The value to herbivores of plant physical and chemical diversity in time and space. Crop Science 47, 382-398. doi:10.2135/ cropsci2006.02.0083

Ramírez-Restrepo CA, Charmley E (2015) An integrated mitigation potential framework to assist sustainable extensive beef production in the tropics. In 'Grassland: A global resource perspective'. (Eds PK Ghosh, SK Mahanta, JB Singh, PS Pathak) pp. 417-436. (Range Management Society of India: Jhansi)

Ramírez-Restrepo CA, Vera RR (2018) Body weight performance, estimated carcass traits and methane emissions of beef cattle categories grazing Andropogon gayanus, Melinis minutiflora and Stylosanthes capitata mixed swards and Brachiaria humidicola pasture. Animal Production Science doi:10.1071/AN17624

Ramírez-Restrepo CA, Kemp PD, Barry TN, López-Villalobos N (2006a) Production of Lotus corniculatus L. under grazing in a dryland environment. New Zealand Journal of Agricultural Research 49, 89-100. doi:10.1080/00288233.2006.9513698

Ramírez-Restrepo CA, Barry TN, López-Villalobos N (2006b) Organic matter digestibility of condensed tannin-containing Lotus corniculatus and its prediction in vitro using cellulase/hemicellulose enzymes. Animal Feed Science and Technology 125, 61-71. doi:10.1016/ j.anifeedsci.2005.05.012

Ramírez-Restrepo CA, Barry TN, Marriner A, López-Villalobos N, McWilliam EL, Lassey KR, Clark H (2010) Effects of grazing willow fodder blocks upon methane production and blood composition in young sheep. Animal Feed Science and Technology 155, 33-43. doi:10.1016/j.anifeedsci.2009.10.003

Ramírez-Restrepo CA, O'Neill CJ, López-Villalobos N, Padmanabha J, McSweeney C (2014) Tropical cattle methane emissions: the role of natural statins supplementation. Animal Production Science 54, 1294-1299.

Rangel JH de A, Gardiner CP (2009) Stimulation of wool growth by Desmanthus spp. as a supplement in a Mitchell grass hay diet. Tropical Grasslands 43, 106-111.

Shelton HM, Lowry JB, Gutteridge RC, Bray RA, Wildin JH (1991) Sustaining productive pastures in the tropics. 7. Tree and shrub legumes in improved pastures. Tropical Grasslands 25, 119-128.

Singh B, Sahoo A, Sharma R, Bhat TK (2005) Effect of polethylene glycol on gas production parameters and nitrogen disappearance of some tree forages. Animal Feed Science and Technology 123-124, 351-364. doi:10.1016/j.anifeedsci.2005.04.033

Stewart JL, Mould F, Mueller-Harvey I (2000) The effect of drying treatment on the fodder quality and tannin content of two provenances of Calliandra calothyrsus Meissner. Journal of the Science of Food and Agriculture 80, 1461-1468. doi:10.1002/1097-0010(200008)80: $10<1461::$ AID-JSFA672>3.0.CO;2-R

Tan HY, Sieo CC, Abdullah N, Liang JB, Huang XD, Ho YW (2011) Effects of condensed tannins from Leucaena on methane production, rumen fermentation and populations of methanogens and protozoa in vitro. Animal Feed Science and Technology 169, 185-193. doi:10.1016/j.anifeedsci.2011.07.004

Tavendale MH, Meagher LP, Pacheco D, Walker N, Attwood GT, Sivakumaran S (2005) Methane production from in vitro rumen incubations with Lotus pedunculatus and Medicago sativa, and effects 
of extractable condensed tannin fractions on methanogenesis. Animal Feed Science and Technology 123-124, 403-419. doi:10.1016/ j.anifeedsci.2005.04.037

Tedeschi LO, Fox DG (2016) 'The ruminant nutrition system: An applied model for predicting nutrient requirements and feed utilization in ruminants.' (XanEdu Publishing Inc.: Acton, MA)

Tedeschi LO, Ramírez-Restrepo CA, Muir JP (2014) Developing a conceptual model of possible benefits of condensed tannins for ruminant production. Animal 8, 1095-1105. doi:10.1017/S17517311 14000974

Tiemann TT, Lascano CE, Kreuzer M, Hess HD (2008) The ruminal degradability of fibre explains part of the low nutritional value and reduced methanogenesis in highly tanniniferous tropical legumes. Journal of the Science of Food and Agriculture 88, 1794-1803. doi: $10.1002 /$ jsfa.3282

Van Soest PJ, Robertson JB, Lewis BA (1991) Methods for dietary fiber, neutral detergent fiber, and nonstarch polysaccharides in relation to animal nutrition. Journal of Dairy Science 74, 3583-3597. doi:10.3168/ jds.S0022-0302(91)78551-2

Vandermeulen S (2016) Trees and shrubs influence the behaviour of grazing cattle and rumen fermentation. $\mathrm{PhD}$ Thesis, Gembloux AgroBiol. Tech-University of Liège, Belgium.

Vandermeulen S, Ramírez-Restrepo CA, Beckers Y, Claessens H, Bindelle J (2018) Agroforestry for ruminants: a review of trees and shrubs as fodder in silvopastoral temperate and tropical ruminant production systems. Animal Production Science 58, 767-777. doi:10.1071/ AN16434

Vera RR, Ramírez-Restrepo CA (2017) Complementary use of neotropical savanna and grass-legume pastures for early weaning of beef calves, and effects on growth, metabolic status and reproductive performance. Tropical Grasslands-Forrajes Tropicales 5, 50-65. doi:10.17138/TGFT (5) $50-65$

Vera RR, Seré C (1985) Evaluation of tropical pasture species with a farming system perspective. In 'Proceedings XV International Grassland Congress'. Kyoto, Japan. (Eds G Kaigi, S Gakkai) pp. 1187-1188. (Science Council of Japan/Japanese Society of Grassland Science: Nishi-nasuno)

Waghorn GC, Shelton ID, McNabb WC (1994) Effects of condensed tannins in Lotus pedunculatus on its nutritive value for sheep. 1. Nonnitrogenous aspects. Journal of Agricultural Science (Cambridge) 123, 99-107. doi:10.1017/S0021859600067824

Wang Y, Douglas GB, Waghorn GC, Barry TN, Foote AG, Purchas RW (1996) Effect of condensed tannins upon the performance of lambs grazing Lotus corniculatus and lucerne (Medicago sativa). Journal of Agricultural Science (Cambridge) 126, 87-98. doi:10.1017/S00218 59600088833 